\title{
PANCREAS PRESERVATION USING REDUCED VOLUMES OF CELSIOR SOLUTION
}

\author{
Preservação pancreática utilizando-se volumes reduzidos da solução de Celsior
}

João Nicoluzzi, PhD; Fábio Silveira, MD

\begin{abstract}
O bjective: The University of Wisconsin solution is the standard preservation liquid for pancreas harvesting. The recently available Celsior solution offers new means to improve the graft preservation, despite of using higher solution volumes. The present work was designed to assess the efficacy of the Celsior solution when used in lower volumes for pancreas preservation. Methods: From January, 2001 to January, 2006, 60 patients were submitted to transplantation, 50 underwent simultaneous pancreas-kidney, and ten pancreas transplantation alone. The last ten consecutive patients received a graft procured with $800 \mathrm{ml}$ of the Celsior solution (eight simultaneous pancreas-kidney and two pancreas alone) which were the subject of this work. Result: The mean cold ischemia time was 11.43 +/- 2.9 hours. No primary endocrine non-function occurred, nor clinical graft pancreatitis. No pancreas was lost due to thrombosis. Two simultaneous pancreas-kidney recipients died after two and three months due to infection in the functioning grafts. A fter a minimum one month follow-up period (1-10 months), all other recipients were alive and well. Currently, eight recipients are insulin-free. Conclusion: These results provide good although indirect evidences that the Celsior solution is as safe as the UW solution in preventing post-reperfusion graft edema and pancreatitis when used in lower volumes for pancreas retrieval.
\end{abstract}

Keywords: Preservation, Pancreas Transplantation, Graft

Institution

Medical School, PUC-PR Brazil and Hospital Angelina Caron - Curitiba - PR

Mailing Address:

Joao Nicoluzzi, PhD

Rua Santo Amaro,118

CEP 80620-330 - Curitiba - Paraná - Brazil

Tel.: 554132646719

E-mail: jenicoluzz@yahoo.com

Recebido em: 03.02 .06

Aceito em: 30.03 .06

\section{INTRODUCTION}

The introduction of the University of Wisconsin (UW ) solution into the clinical practice allowed a safe and extended preservation of the pancreas for up to 30 hours with good graft function. ${ }^{1}$ Therefore, U W is the standard to judge any new preservation solution intended to be used in pancreas transplantation.

A sa new preserving solution, the Celsior solution has recently become available, and it theoretically may offer new means to improve the graft preservation quality and probably the graft outcome as well.2 The Celsior solution is a type of extracellular solution initially successfully used in heart transplantation, ${ }^{2}$ and more recently showed to bean effective alternative to the UW solution in preserving thoracic and abdominal organs such as lung, ${ }^{3}$ kidney, ${ }^{4}$ small intestine ${ }^{5}$ and pancreas. ${ }^{6}$ Due to its low viscosity, antioxidant and anti-edema properties, the Celsior solution may be particularly suitable to the pancreas preservation. A nother difference between both solutions is that the $C$ elsior solution requi res higher fluid volume during the organ retrieval, as recommended by the manufacturing company.

The present work was designed to assess the ef ficacy of the Celsior solution as preservation solution for pancreas al lograft when used in lower fluid volumes.

\section{METHODS}

Studied population. From January, 2001 to J anuary, 2006, 60 patients were submitted to pancreatic transplantation, 50 underwent 
simultaneous pancreas-kidney transplantation (SPK), and ten pancreas transplantation alone (PA) at our center. The last ten consecutive patients received a graft procured with CS (8SPK s and 2 PA) using lower volumes of fluid ( $800 \mathrm{ml})$ and these are the population of this work. The study protocol was approved by the institution's board of ethics. The mean age at the time of the transplant was 33 years (range 21-55). Eight subjects were male and two female. A II patients were submitted to systemic-bladder drainage.

The values of the post-operative urinary amylase levels (U/L) respectively on day $1,3,5,7,10$, and 30 in both groups were registered. Values from the UW group were obtained from our historical database using ten patients with similar characteristics to the CS group.

Immunosuppression. N one of the patients submitted to SPK received any induction therapy regardless their PR A . Patients submitted to PA received Thymoglobulin ( $0.5 \mathrm{mg} / \mathrm{kg}$ body weight) as an induction therapy as a 7-day course. A II patients received only oral tacrolimus (TAC) started immediately post-transplant in $0.1-0.2 \mathrm{mg} / \mathrm{kg}$ oral dose divided in two doses, and the $12 \mathrm{hs}$ level was kept at $10-12 \mathrm{ng} / \mathrm{ml}$ along the first three months. Oral M M F begun immediately after the transplant at 2-3 $\mathrm{g} /$ day in two to four divided doses. Corticosteroids were administered as methylprednisolone $500 \mathrm{mg}$ intra-operatively and $250 \mathrm{mg}$ on the postoperative day 1 , and next tapered to $30 \mathrm{mg} /$ day oral prednisone by day 7-10.

A II donor procedures were undertaken using the same surgical team who procured pancreas grafts according to a well-standardized technique that entails a complete preliminary graft dissection before aortic cross-clamping and graft perf usion exclusively through the aorta. Perfusion volumes were limited to $800 \mathrm{ml}$ of the CS solution, regardless the donor weight; as we had done before with the UW solution to avoid pancreatitis. Pancreas grafts were not reflushed ex-vivo, and they were put into a cold storage of CS solution until the implantation. All donors aged less than 55 years, and no history of diabetes, pancreatic disease, or pancreatic trauma were deemed potentially eligible for pancreas donation. Hyperglycemia or hyperamylasemia, hemodynamic instability requiring either low or high vasopressors doses and long periods of intensive care unit stay were not considered absolute contraindications. The final decision to accept a pancreas for transplantation was based on the gross appearance of the graft and vessels and on the visceral perfusion quality.

\section{RESULTS}

No cardiac or hemodynamic incidents were observed during the organ revascularization. No electrolyteor hematological abnormalities were observed postoperatively. The mean cold ischemia time was 11.43 +/- 2.9 hours (range: 6-15 hours). The mean donor age was 23 years (range 18-28). A Il of them were using high-dose catecholamines.

The post-operative urinary amylase $(\mathrm{U} / \mathrm{L})$ levels in both groups (CS and UW) are shown in graphics 1 and 2, respectively, with very similar results.

No primary endocrine pancreas non-function nor clinical graft pancreatitis occurred. No pancreas was lost due to thrombosis. One recipient required a relaparotomy due to an acute abdomen (negative exploration). Two SPK recipients died respectively at two and three months due to infection in the functioning grafts. After a minimum follow-up period of one month (1-10 months),
Graphic 1 - Urinary amylase levels in the Celsior solution group

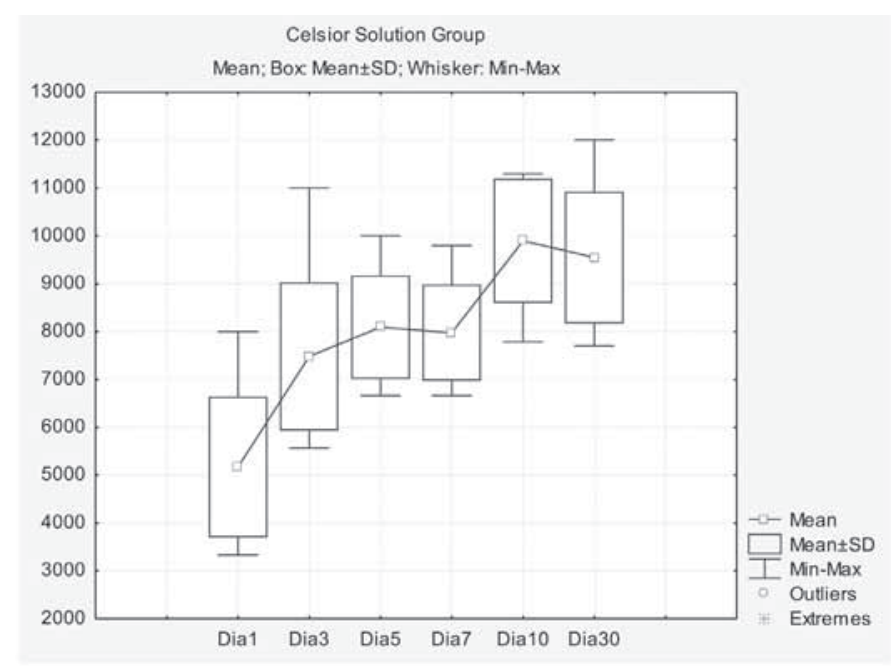

Graphic 2 - Urinary amylase levels in the UW group

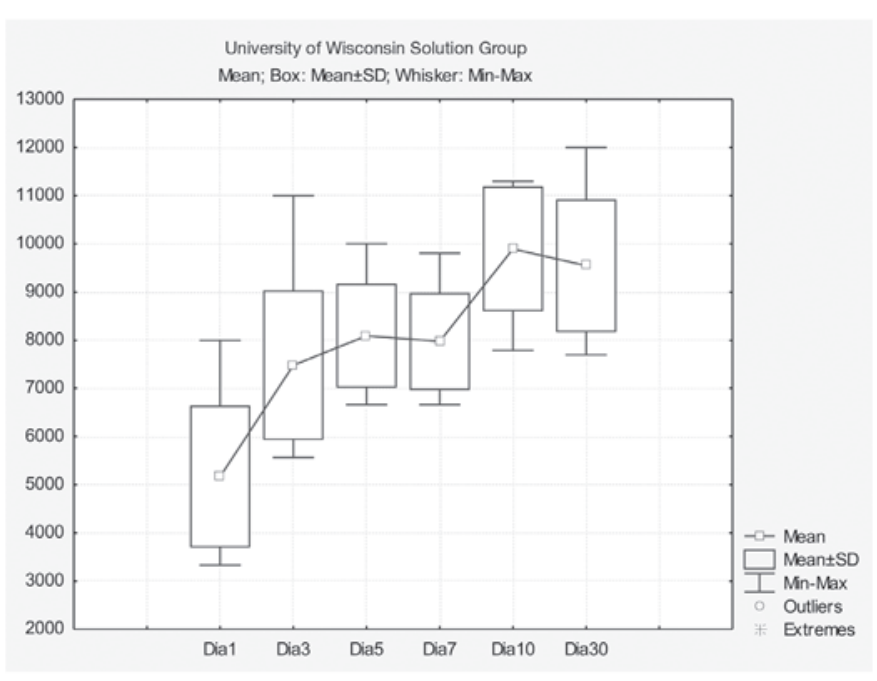

all other recipients are alive and well. Two rejection episodes were diagnosed in two recipients (1 SPK and 1 PA). A Il rejections were reversed with a course of T-cell-depleting therapy. Currently eight recipients are insulin-free.

\section{DISCUSSION}

The UW solution ${ }^{8,9}$ is now considered the standard preservation solution for liver, kidney, and pancreas transplantation, but its high potassium content has been accused of potentially causing calcium-associated contracture, leading to contraction of glomerular capillaries after kidney transplantation. CS is designed to minimize hypothermia-induced cell swelling and interstitial edema caused by the presence of such membrane-impermeable substances such as mannitol and lactobionate. It also is characterized by a marked buffer capacity caused by the presence of $30 \mathrm{mmol}$ of histidine. ${ }^{10}$ 
From such perspective, the UW solution differs from CS in that it contains raffinose, characterized by a greater molecular weight than mannitol. CS also contains oxygen radical scavengers, with reduced glutathione, but mannitol and histidine also have role in preventing oxidative injury related to post-reperfusion free radical production. Conversely, the rapidly oxidized glutathione in shelf-stored UW solution definitely lacks this important protective effect. The role of the glutamate in CS is to yield adenosine triphosphate under anaerobic conditions, preventing intracellular acidosis and permitting the energy-dependent systems that normally maintain the calcium, sodium, and potassium homeostatic functions. ${ }^{11}$

Our option to use different CS perfusion volumes, as prescribed by the CS manufacturing company, ${ }^{7}$ was trying to avoid the volume overload to the graft with consequent edema, and the associated pancreatitis with risk of thrombosis. ${ }^{12} \mathrm{~A}$ II other retrievals had al ways respected a maximum volume of $800 \mathrm{ml} \mathrm{UW}$ solution, regardless the donor weight as previously described.12 It seems that such policy did not affect the results, as in the present series no episode of acute pancreatitis was recorded, no primary endocrine pancreas nonfunction neither graft thrombosis occurred. Finally, the comparison of the urinary amilasemia was very similar in both groups.

\section{CONCLUSION}

These results provide good, although indirect, evidences that the CS solution is as safe as U W solution in preventing post-reperfusion graft edema and pancreatitis as well as it seems that it can be safely used in the same amount for pancreas retrieval.

\section{RESUMO}

O bjetivo: A solução da Universidade de W iscosin é o líquido de preservação padrão para captação de pâncreas. M ais recentemente, a solução de Celsior passou a oferecer novas possi bilidades para a mel horia da preservação do enxerto, entretanto é necessário maior volume de solução. 0 presente estudo avalia a eficácia da solução de Celsior, quando utilizada em menores volumes do que o recomendado para preservação pancreática. M étodos: Entre janei ro de 2001 e janei ro de 2006, 60 pacientes foram submetidos a transplante, sendo que 50 del es foram submetidos a transplante de pâncreas-rim simultâneo e dez a transplante de pâncreas isolado. Os dez últimos pacientes, de maneira consecutiva, receberam enxerto captado, utilizando-se $800 \mathrm{ml}$ da solução de Celsior (oito pâncreas-rim si multâneo e dois pâncreas isolado) e foram avaliados por esse estudo. R esultado: 0 tempo médio de isquemia foi de $11.43+/-2.9$ horas. Não ocorreu disfunção endócrina primária do enxerto, nem pancreatite do enxerto, clinicamente comprovada. Não houve perda de enxerto por trombose. Dois pacientes submetidos a transplante de pâncreas-rim simultâneo morreram no segundo e terceiro mês devido à infecção com enxertos funcionantes. A pós um período de follow-up mínimo de um mês (1-10 meses), todos os outros pacientes estavam vivos com enxertos funcionantes, sem necessidade de insulina. C onclusão: O s resultados demonstram claras evidências de que a solução de C el sior é tão segura quanto a solução de UW na prevenção do edema do enxerto pós-perfusão e pancreatite, quando utilizada em menores volumes para captação.

Descritores: Preservação, Transplante Pancreático, Enxerto

\section{REFERENCES}

1. Stratta RJ, Taylor RJ, Gill IS. Pancreas transplantation: a managed cure approach to diabetes. Curr Probl Surg. 1996;33:709.

2. Menasche P, Termignon JL, Pradier F, et al. Experimental evaluation of Celsior ${ }^{\circledR}$, a new heart preservation solution. Eur J Cardiothorac Surg. 1994;8:207.

3. Roberts RF, Nishanian GP, Carey JN, et al. A comparison of the new preservation solution Celsior to Euro-Collins and University of Wisconsin in lung reperfusion injury. Transplantation. 1999;67:152.

4. Baldan N, Toffano M, Cadrobbi R, et al. Kidney preservation in pigs using a new organ preservation solution. Transplant Proc. 1997;29:3539.

5. Minor T, Vollmar T, Menger MD, et al. Cold preservation of the small intestine with the new-Celsior solution. Transpl Int. 1998;11:32.

6. Baldan N, Rigotti P, Furian L, et al. Pancreas preservation with Celsior solution in a pig autotransplantation model: comparative study with University of Wisconsin solution. Transplant Proc. 2001;33:873.
7. Boggi U, Vistoli F, Del Chiaro M, et al. Pancreas preservation with University of Wisconsin and Celsior solutions. A single-center, prospective, randomized pilotstudy. Transplantation. 2004;77:1186.

8. Hefty T, Fraser S, Nelson K, et al. Comparison of UW and Euro-Collins solutions in paired cadaveric kidneys. Transplantation. 1991;53:491.

9. Nardo B, Bellusci R, de Badiali GL, et al. Ultrastructural aspects of the iliac arteries of multiorgan donor preserved in University of Wisconsin solution for 48 hours. Transplant Proc. 1992;24:2447.

10. Susimoto R, Lindeli SL, Southard JH. A comparison of histidine-lactobionate and UW solution in 48-hour dog liver preservation. Transplantation. 1992;54:610.

11. Pisarenko OI, Solomatina ES, Ivanov VE, et al. On the mechanism of enhanced ATP formation in hypoxic myocardium caused by glutamic acid. Basic Res Cardiol. 1985;80:126.

12. Troppman C, Gruessner AC, Benedetti E, et al. Vascular graft thrombosis after pancreas transplantation: univariate and multivariate operative and non operative risk factors analysis. J Am Coll Surg. 1996;182(4):285. 